\title{
Extra Cellular Lipase Production, Purification and Characterization Using Bacillus Subtilis in Submerged State Fermentation
}

\author{
Anitha Muthusamy and Leena Grace Beslin* \\ Department of Biotechnology, Selvamm Arts \&Science College (Autonomous), India
}

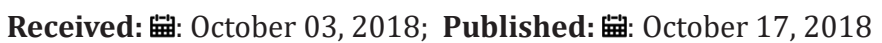

*Corresponding author: Leena Grace Beslin, Department of Biotechnology, Selvamm Arts \& Science College (Autonomous), Tamilnadu, India

Abstract

Lipases are produced extracellular by the bacterial strain Bacillus subtilis in submerged state fermentation. It was purified from the cell free culture broth by ammonium sulphate precipitation at 70\% saturation followed by purification solvent precipitation by acetone and ethanol. DS- PAGE analysis indicated that the enzymes, protein molecular mass was $19.4 \mathrm{kDa}$. The enzyme activity was maximum and growth 72 hours of incubation time, with an activity $(0.95 \mathrm{U} / \mathrm{ml})$. Lipase activity was maximal at $1 \%$ concentration of the substrate. Olive oil produced (32.67) units of lipase which was achieved at best induce for lipase production enzyme activity. The optimum PH 8 for the activity of lipase was recorded in the present study.

\section{Introduction}

Lipase is produced by various microbes, bacteria, fungi, yeast, mammals and plants in large amounts. Lipase have been used extensively is oleo chemical industry and dairy industry [1] and to produce the structural triglycerides [2]. Extracellular lipase produced by microorganisms is being investigated for its potential application in various industrial processes like detergents, oils, fatty acids and diary coupled with enormous therapeutic uses [3]. Recently, lipases find a number of potential applications in detergent industry, oleo chemical industry, paper manufacturing industry, organic chemical processing, nutrition cosmetics, pharmaceuticals and agrochemical [4]. In leather industry, conventional decreasing is carried out by using kerosene, petrol and other solvents or by aqueous emulsification procedures using detergents. There are many industries pollution problems as well as hazards associated with the use of solvents and detergents. Enzymatic decreasing of hides and skins is suggested as viable alternative to compact pollution problems caused by the use of solvents and surfactants [5]. Microbial lipase is available as commercial production, the majority of which are used in detergents, cosmetics production, food technology and chemical industry. Lipases are biocatalysts because they act under mild conditions, are highly stable in organic solvents, show broad substrate specificity and usually high region and or stereo selectivity in catalysis $[6,7]$ reported that the increased production of extracellular lipase in the culture of microorganism's growth in the presence of triglycerides and other lipids. Some important lipase producing bacterial genera includes Bacillus, Pseudomonas and Acnetobacter. Bacterial lipase is mostly extracellular and are produced by submerged fermentation [8-12].

Multi-faceted microbial lipases (tricyglycerol acylhydrolase, E.C.3.1.1.3) have emerged as key enzymes in swiftly growing modern biotechnology lipases are indispensable for the bioconversion lipids (triacylglycerols.) from one organism to another and within the organisms. In addition to their biological significance, lipase have tremendous potential in areas such as food technology, bio medical sciences and chemical industry, [1315]. Lipases are glycoproteins, but some extracellular bacterial lipases are lipoproteins [16] reported that the enzyme production in most of the bacteria is affected by certain polysaccharides. Many different bacterial species produce lipases, which hydrolyze the esters of glycerol with preferably long chain fatty acids. They act at the interface generated by a hydrophobic liquid substrate in a hydrophilic aqueous medium [17].

\section{Materials and Methods}

In the present study, the bacillus subtilis was used for the production of extracellular lipase by submerged state fermentation by using various substrates. The Bacillus subtilis were identified from oil refineries soil sample from vennandur, Namakkal. 


\section{Isolation of Soil Samples}

Bacteria are omnivorous, saprophytic, or heterotrophic organisms that occupy nearly every conceivable environmental niche. The soil sample was collected from then oil refineries. Sample was collected by using sterile gloves, scalpel and placed in sterile container. Serial dilution was carried out to isolate bacterial from soil. For this $10 \mathrm{ml}$ sterile distilled water was taken in a test tube. To this $1 \mathrm{gm}$ of finely pulverized air dried soil was added. The tube was vigorously vortexed for 3 minutes to obtain uniform suspension of microorganisms. A series of tubes, labeled as 10-1, 10-2 to 10-7 were filled with $9 \mathrm{ml}$ sterile distilled water. $1 \mathrm{ml}$ of diluted sample was transferred to the tube marked 10-1 and vigorously vortexed. The process was repeated up to 10-7. Pour plate method was used to culture bacteria using nutrient agar media. Three sterile Petri plates was taken and labeled as $10-2,10-3$ and 10-4. To these $1 \mathrm{ml}$ aliquots each from 10-2, 10-3 and 10-4 serial dilution were transferred to respective Petri plates [18-20]. Then approximately $15 \mathrm{ml}$ of cooled $\left(45^{\circ} \mathrm{C}\right)$ nutrient agar medium was added to each Petri plate and the inoculums were mixed by gentle rotation of Petri plates. After solidification of medium the plate were incubated for 24 hours at $37^{\circ} \mathrm{C}$.

\section{Media and Culture Conditions}

The Bacillus subtilis culture was grown in tributyrin agar medium composition of medium $2.5 \mathrm{~g}$ of peptone, $3.0 \mathrm{~g}$ of beef extract, $1.5 \mathrm{~g}$ of agar and $1 \mathrm{ml}$ of tributyrin was dissolved in $100 \mathrm{ml}$ of distilled water. The ph. was adjusted with 7.2.

\section{Isolation of Lipase Producing Colonies from Tributyrin Agar Plates}

The tributyrin agar medium was prepared and autoclaved for $121^{\circ} \mathrm{C}$ at 15 minutes. The medium was poured into sterilized Petri plates and allowed to solidify and kept for contamination check for 24 hours. The obtained culture was inoculated into two labeled plates one each of ph. 7.2. the plates were kept for incubation of 48 hours at $37^{\circ} \mathrm{C}$ in inverted position.

\section{Preparation of Substrate}

The various substrate source of olive oil, neem oil, castor oil, and gingelly oil were used for production of lipase enzyme from Bacillus subtilis by submerged state fermentation. The substrates were obtained from local market at perundurai, erode.

\section{Lipase Production Medium}

The olive oil borth was used in the present study. The broth contains $5 \mathrm{~g}$ of peptone, $3 \mathrm{~g}$ of yeast extract, $2 \mathrm{~g}$ of beef extract and $5 \mathrm{ml}$ of lipid substrates olive oil, neem oil, and castor oil, gingelly oil, dissolved in $100 \mathrm{ml}$ of distilled water. The pH. was adjusted with 7.2.

\section{Preparation of Inoculums and Production of Lipase}

Preparation of Inoculum: Single colony of Bacillus subtilis was inoculated in $10 \mathrm{ml}$ of olive oil borth in $250 \mathrm{ml}$ conical flask incubated at $37{ }^{\circ} \mathrm{C}$ with agitation on rotator shaker at $240 \mathrm{rpm}$ for 24 hours.

Production of Lipase: $5 \mathrm{ml}$ of inoculums was inoculated into $100 \mathrm{ml}$ of fresh fermentation medium (the broth contains $2 \mathrm{~g}$ of peptone, $2 \mathrm{~g}$ of glucose, $0.5 \mathrm{~g}$ of potassium dihydrogen phosphate, $0.1 \mathrm{~g}$ of diammonium sulphate, $0.1 \mathrm{~g}$ of diammonium carbonate, $0.1 \mathrm{~g}$ of magnesium sulphate and $1 \mathrm{ml}$ of olive oil was dissolved in $100 \mathrm{ml}$ of distilled water [21-25]. The PH was adjusted with 7.2) in $500 \mathrm{ml}$ of conical flask and incubated at $37^{\circ} \mathrm{C}$ for 96 hours in the shaker at 100rpm.

Extraction of Lipase: After the submerged state fermentation, the enzyme was extracted from fermentation medium, $5 \mathrm{ml}$ of production medium was withdrawn from the production flask and centrifuged at $10,000 \mathrm{rpm}$ for 30 minutes at $4^{\circ} \mathrm{c}$. The clear supernatant served as a crude enzyme lipase source.

Enzyme Assay: Lipase activity was assayed by titrimetric (olive oil-substrate emulsion) method [26]. The assay mixture was prepared by $1.0 \mathrm{ml}$ of substrate emulsion the composition of substrate emulsion contains $70 \mathrm{ml}$ of emulsification, reagent $117.6 \mathrm{~g}$ of sodium chloride, $0.4 \mathrm{~g}$ of potassium dihydrogen phosphate, $5.4 \mathrm{ml}$ of glycerol, $10 \mathrm{ml}$ of gum Arabic was dissolved in $1000 \mathrm{ml}$ of distilled water) and $30 \mathrm{ml}$ of olive oil, $0.8 \mathrm{ml}$ of $0.2 \mathrm{M}$ potassium phosphate and $0.2 \mathrm{ml}$ of enzyme aliquot in $100 \mathrm{ml}$ of conical flask and incubated at $55^{\circ} \mathrm{c}$ for 30 minutes. After incubation $2.0 \mathrm{ml}$ of acetone. Ethanol mixture was added to terminate the reaction and titrate the above aliquots with $0.1 \mathrm{~N} \mathrm{NAOH}$ using $1 \%$ phenolphthalein as the indicator, end point is the appearance of pale pink colour. One unit of lipase activity is defined as the amount of enzyme required to liberate $1 \mathrm{mg}$ of fatty acid $/ \mathrm{ml} / \mathrm{min}$.

Lipase activity $\mathrm{u} / \mathrm{ml} / \mathrm{min}=$ volume of $\mathrm{NaOH} \times$ normality of $\mathrm{NaOH} \times 7 \times 100$ Incubation time

\section{Purification of Lipase}

Salt Precipitations: The stability of protein is markedly affected by the ionic strength increase. solubility of the protein also increases this is referred to as "salting in". However, beyond a certain point, the solubility begins to decrease, and this is known as salting out.

Lipase Precipitation by Ammonium Sulphate: Ammonium sulphate was used for fractional precipitation of proteins. It was available in highly purified form, has great solubility allowing for significant changes in the ionic strength. The changes in the ammonium sulphate concentration of a solution by adding a solution of known saturation to crude enzyme extract. The $30 \%$ salt cut was given to the supernatant was collected from submerged state fermentation. To this $16.6 \mathrm{~g}$ of ammonium sulphate was added respectively. No precipitation was observed in case of submerged fermentation, the $70 \%$ salt cut was added (21.1g of Ammonium Sulphate). Ammonium sulphate was added very slowly with continuous stirring of the solution on a magnetic stirrer in cold conditions. The solution was centrifuged at 10,000rpm for 10 minutes at $4{ }^{\circ} \mathrm{C}$. These pellets were collected and dissolved in $10 \mathrm{ml}$ of $50 \mathrm{mM}$ Tris Hcl solution.

Dialysis: The precipitate was collected by centrifugation the extract at $10,000 \mathrm{rpm}$ for 10 minutes at $4{ }^{\circ} \mathrm{C}$. The precipitate was dissolved in $10 \mathrm{ml}$ of $50 \mathrm{~mm}$ tris $\mathrm{Hcl}$ and subjected to dialysis. About $10 \mathrm{~cm}$ size of dialysis bag was successively boiled in $100 \mathrm{ml}$ of distilled water, $2 \%$ sodium bicarbonate and IMM EDTA solution and 
again $100 \mathrm{ml}$ of distilled water for $10 \mathrm{~min}$ at $100^{\circ} \mathrm{C}$. Then the dialysis bag was cooled to room temperature and kept in refrigerator for $30 \mathrm{~min}$. the dissolved enzymes were transferred to dialysis bag of one end. The bag was tightly tied, and dialysis bag was suspended in a beaker containing distilled water with the help of glass rod. This set up was kept in refrigerator overnight.

Solvent Precipitation Using Acetone: The dialyzed enzyme solution was subjected to acetone precipitation at $60 \%$ saturation for $30 \mathrm{~min}$ in the magnetic stirrer. The content of the tubes was subjected to centrifuge at $10,000 \mathrm{rpm}$ for $10 \mathrm{~min}$, the pellets were dissolved in $5 \mathrm{ml}$ of 50MM Tris HCL (PH 8.0) and dialyzed against the same buffer and the enzyme activity was assayed.

Ethanol Precipitation: The dialyzed enzyme acetone precipitation solution was subjected to ethanol precipitation at 705 saturation for 30 minutes in the magnetic stirrer. The content of the tubes was subjected to centrifuge at $10,000 \mathrm{rpm}$ for 10 minutes, the pellets were dissolved in $5 \mathrm{ml}$ of 50MM Tris Hcl buffer (PH-8.0) and the enzyme activity was assayed.

Molecular Mass Determination by SDS - PAGE: PAGE under non - denaturing conditions and SDS - PAGE was carried out as determine by Laemmli. For non-denaturing PAGE, the separating gel consisted of $12 \%$ polyacrylamide and the stacking gel consisted of $5 \%$ polyacrylamide. Sample of $12 \mathrm{ml}$ and $8 \mu \mathrm{l}$ of sample buffer with $50 \mathrm{~m}$ M Tris Hcl,10 \% SDS 0.1\% bromophenol blue mercaptoetanol and glycerol were loaded into the well. Molecular mass markers were purchased from Bangalore genei and were run parallel to the samples. Electric current of $50 \mathrm{~V}$ was supplied using a standard power pack. The gel was stained using Coomassie brilliant blue and then distained using a mixture of Methanol, Glacial acetic acid and distilled water.

Effect of pH on the Lipase Activity: The effect of $\mathrm{PH}$ on different inducers on lipase activity was studied. To determine the optimum PH for the activity of lipase, the medium with different PH were inoculated with culture and incubated at $37{ }^{\circ} \mathrm{C}$ for 96 hours. $\mathrm{PH}$ ranges of 6-9 were used.

Effect of Substances for Lipase Enzyme Activity: The effect of different inducers on lipase activity was studied by growing the culture in peptone medium at $37^{\circ} \mathrm{C}$ for 96 hours. Inducers like olive oil, gingelly oil, Castrol oil and neem oil were used (1\%).

\section{Results and Discussion}

\section{Isolation of Lipase Producing Colonies}

The Bacillus subtilis was produced the lipase enzyme by checked with lipid hydrolysis in tributyrin agar medium. All the plates were formed the clear zone around the colonies of Bacillus subtilis. A clear zone around the colonies was observed due to degradation of fat substrates in the medium. The degradation of fats due to secreion of the lipase enzyme by Bacillus subtilis.

\section{Production of Purification of Lipase Enzyme}

After 4 days incubation of (production medium olive oil broth) with submerged state fermentation the crude extract was prepared by centrifuge. The supernatant was used as enzyme source. The crude extract was successively precipitated at saturation of $30 \%$ and $70 \%$ in magnetic stirrer. The precipitate was collected and dissolved in $10 \mathrm{ml}$ of $50 \mathrm{mM}$ Tris $\mathrm{Hcl}$. The diluted precipitate was subjected to dialysis and the dialysed enzyme was purified.

\section{Effect of Substrates for Production of Lipase Bacillus Subtilis}

The B. subtilis was cultured in olive oil broth of submerged state fermentation by various substrates of the castor oil, Neem oil and Gingelly oil. The present study indicated that the higher lipase production was observed in olive oil used as a source of lipid substrate [27-31]. The lipase enzyme activity was also high $(32.67 \mu \mathrm{l} / \mathrm{ml} / \mathrm{min})$ in olive oil substances, followed by gingelly oil $(28 \mathrm{u} / \mathrm{ml} / \mathrm{min})$, castor oil $(25.67 \mathrm{u} / \mathrm{ml} / \mathrm{min})$ and Neem oil $(23.33 \mu \mathrm{l} /$ $\mathrm{ml} / \mathrm{min}$ ) by assay of olive oil emulsion method. The maximum enzyme production was observed by olive oil > gingelly oil > castor oil $>$ and neem oil respectively (Figures 1-3), when compare to other lipase substrates olive oil containing high content of lipid substrates were subjected to degradation of olive oil. In the present study high level of lipase enzyme production, enzyme activity and growth of bacillus subtilis was observed in olive oil broth followed by $32.67 \mu \mathrm{l} / \mathrm{ml} / \mathrm{min}$ in submerged state fermentation (Tables $1-3$ ).

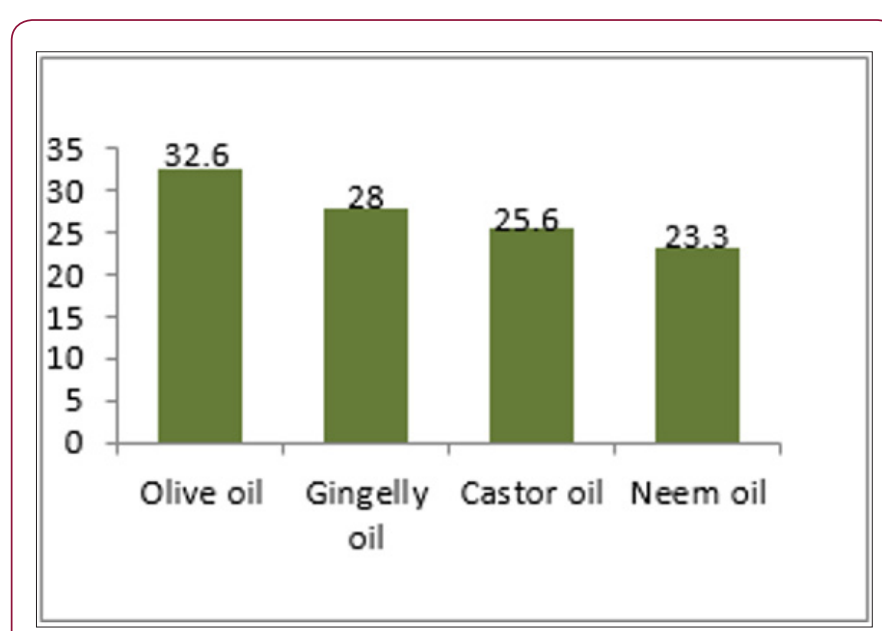

Figure 1: Effect of substrates.

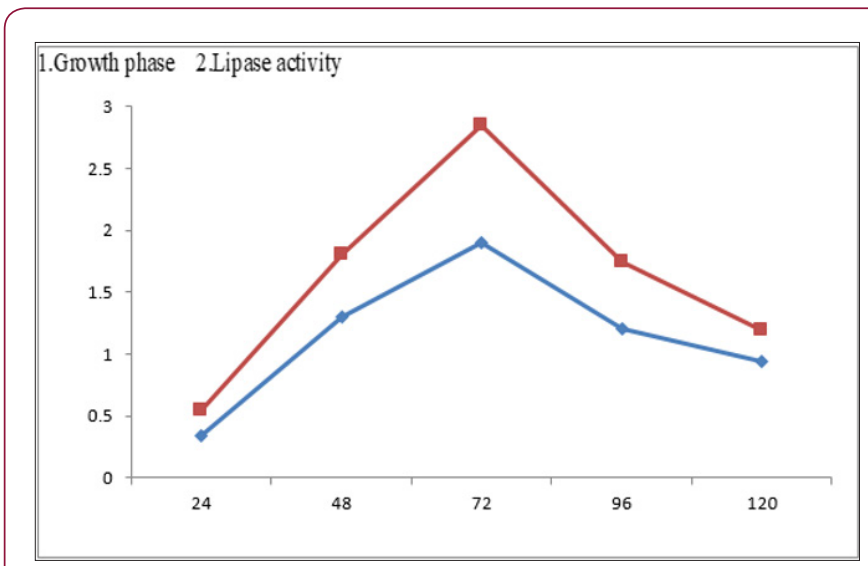

Figure 2: Growth curve and lipase activity of Bacillus subtilis. 


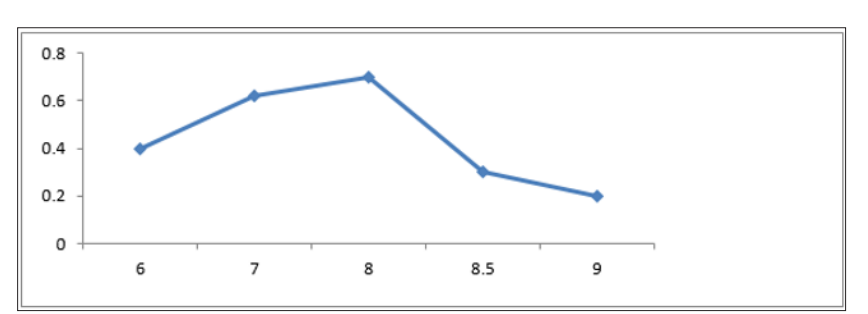

Figure 3: Effect of different $\mathrm{pH}$ on lipase enzyme activity.

Table 1: Lipase enzyme production from submerged state fermentation by Bacillus subtilis.

\begin{tabular}{|c|c|c|}
\hline S. No & $\begin{array}{c}\text { Fermentation Medium } \\
\text { With Different Substrates }\end{array}$ & $\begin{array}{c}\text { Enzyme Production(u/ml/ } \\
\text { min) }\end{array}$ \\
\hline 1 & Olive Oil & 32.67 \\
\hline 2 & Gingelly Oil & 28.00 \\
\hline 3 & Castor Oil & 25.67 \\
\hline 4 & Neem Oil & 23.33 \\
\hline
\end{tabular}

Table 2: Lipase enzyme production from submerged state fermentation by Bacillus subtilis.

\begin{tabular}{|c|c|c|}
\hline Hours of Incubation & OD Value at 550nm & Lipase Activity(u/ml) \\
\hline 24 & 0.34 & 0.2 \\
\hline 48 & 1.3 & 0.5 \\
\hline 72 & 1.9 & 0.95 \\
\hline 96 & 1.2 & 0.55 \\
\hline 120 & 0.94 & 0.25 \\
\hline
\end{tabular}

Table 3: Effect of different $\mathrm{pH}$ on lipase enzyme activity.

\begin{tabular}{|c|c|c|}
\hline S. No & PH & Lipase Activity(u/ml) \\
\hline 1 & 6 & 0.4 \\
\hline 2 & 7 & 0.67 \\
\hline 3 & 8 & 0.7 \\
\hline 4 & 8.5 & 0.3 \\
\hline 5 & 9 & 0.17 \\
\hline
\end{tabular}

\section{SDS-PAGE}

For determining the molecular mass of the lipase SDSPAGE (7.5-1.5\% polyacrylamide gradient) was performed on electrophoretically purified lipase extracted (by ammonium sulphate precipitation) from slices of non-denaturing gel corresponding to the active lipase bands. Enzyme preparation from different sources were run in parallel to a standard known protein mixture (high molecular weight, kit from sigma) silver staining was used to detect protein bands [32-35]. Silver stains are useful for the detection of Nanogram amount of proteins are nucleic acids in acrylamide gels (or) on various membranes. They are more sensitive than organic stains [36-40]. Silver images of protein or nucleic acid patterns are produced by a difference in the oxidation - reduction potential in regions occupied by nucleic acid or proteins compare to the surrounding gel or membrane $[41,49]$. This redox potential catalysis the reduction of ionic to metallic sliver. A positive (dark) image will be produced if the region occupied by nucleic acid has higher redox potential than the surrounding region. Experiments with nucleic acids and their components have implicated the purines as the active subunits in the silver staining reaction [50-56]. Estimation of molecular weight of lipase by gel filtration revealed 19000 and31000 daltons respectively. These values correspond to data previously published for microbial lipases [57-62].

\section{Conclusion}

In the present study bacillus subtilis was used to produce the lipase enzyme by submerged state fermentation.

\section{References}

1. Aries Barros Mr, Taipa Ma, Carbal Jms (1994) Isolation and Purification of lipase. In: Wooley P, Petersen SB (Eds.). Lipases their structure, biochemistry and application, Cambridge University Press, Cambridge, UK: pp. 243- 270.

2. Akhtar MW, Mirza AQ Chughtai MID (1980) Lipase induction in mucor hiemalis. Appl Env Microbiol 40(2): 257-263.

3. Antonian E (1988) Recent advances in the purification, characterization and structure determination of lipases. Lipids 23(12): 1101-1106

4. Brockman HL (1984) General feature of lipolysis in lipase: reaction sceme interfacial structure and experimental approaches in lipases. In: Borgstron B and Brockman HL (Eds.). Elsev Sci Publis, Amsterdam: p. $1-46$.

5. Davranov K (1994) Microbial lipases in biotechnology (review) Appl biochem microbial 30: 527-534.

6. Ghosh PK, Saxena RK, Gupta R, Yadev RP, Davidson (1996) Microbial Lipases. Production and applications. Sci Prog 79: 119-157.

7. Gill I, Valivety R (1997) Trends in Biotech No15: 470-478.

8. Gupta R, Rathi P, Gupta N, Bradoo S (2003) lipase assays for conventional and molecular screening; an overview. Biotechnology Appl Biochem 37(1): 63-71.

9. Gupta R, Gupta N, Rathi P (2004) Bacterial lipases: an overview of production, purification and biochemical properties. Appl. Microbiol. Biotech 64: 763-781.

10. Gupta M, Mehra G, Gupta R (2004) A glycerol inducible thermostable lipase from bacillus sp. Medium optimization by a placket Burman design and by responses surface methodology. Can J Microbiol 50(5): 361-368.

11. Haalck L, Hedrich H, Hassink J, Spener F (1992) Prog. Biotech 8: 505572.

12. Haalck L, Kallabis B, Schoemaker M, Cammann K, Spener F (1991) Lipases for biosensors. Fat Sci Tech 93: 415- 416.

13. Hofelmann M, Kittsteiner Eberle R, Schreier P (1983) Ultrathin layer agar gels: a novel print technique for ultrathin layer isoelectric focusing of enzymes. Anal Biochem 128: 217.

14. Hong Mc, Chang Mc (1998) purification and characterization of a alkaline lipase from a newly insolated Acinetobacter radio resistens CMC 1. Biotech Let 20(11): 1027-1029.

15. Huan Dong, Shujan Gao, Si Ping Han, Shu Gin Lao (1999) purification and characterization of a pseudomonas sp, lipase and its properties in nonaqueous media. biotechnology appl. Biochem 30: 251-256.

16. Jaegar KE, Dijkstra Bw, Reetz Mt (1999) bacterial biocatalysts molecular biology, three dimensional structures and biotechnological applications of lipases. Annu Rev. Microbial 53: 315-351.

17. Jaeger KE, Ransac S, Dijkstra Bw, Colson C, Heuvel M, et al. (1994) bacterial lipases. FEMS Microbial Rev 15(1): 29-63. 
18. Jaegar KE, Eggert $\mathrm{T}$ (2002) lipases for biotechnology curr Opin biotech 13(4): 390-397.

19. Jaegar KE, Reetz MT (1998) Microbial lipases form versatile tools for biotechnology. Trends Biotech 16(9): 396-403.

20. Jansen AEM, Vaidya AM, Halling PJ (1996) Eng Microb Tech 18: 340-346.

21. Kao A (1995) Industrial applications of microbial lipases Jpn Pat J p. 0713381.

22. Kim KK, Son, HK, Shin DH, Hwang KY (1997) structure 5: 173-185.

23. Lasuisse E, Schenack K, Colson C (1993) Purification and preliminary characterization of the extracellular lipase of Bacillus subtilis 168, an extremely basic pH tolerant enzyme eur j Biochem 216(1): 155-160.

24. Lonsane BK, Ghidyal NP, Budiatman S, Ramakrishna SV (1989) Engineering aspect of solid state fermentation. enz Microbial Tech 7(6): 255-265.

25. Lotti M, Monticelli S (1998) Physiological control on the expression and secretion of candida rugosa lipase. Chem Phys lipids 93(1-2): 143-148.

26. Macrae AR (1983) lipase catalyzed interstratifications of oils \& fats. J am oil chem soc 60: 243-246.

27. Macrae AR, Hammond C (1985) Present and future applications of lipases. Biotech Genet Eng Reve 3(1): 193-217.

28. Merril CR (1987) Development of mechanisms of silver stains for electrophoresis. Acta Histo chem. Cytochem 19: 665-667.

29. Merril CR (1990) Silver staining of proteins and DNA Nature 343: 779780.

30. Merril CR, Pratt ME (1986) A silver stain for the rapid quantitative detection of proteins, nuclei acids on membranes or thin layer plates. Analytical Biochemistry 156(1): 96-110.

31. Nahas E (1988) Control of lipase production of Rhizopus oligosporous under various growth conditions. J Gen Microbial 134: 227-233.

32. Ota Y, S Miyairi, K Yamada (1968) Sterol requirements for lipase production by candida cylindracea. Agri Bol Chem 32(12): 1476-1478.

33. Pandey A, Benjamin S, Soccol CR, Nigam P, Krieger N, et al. (1999) The realm of microbial lipases in biotechnology. biotechnol appl Biochem 29: $119-131$.

34. Pandey A, Sailas Benjamin, Carlos R, Poonam Nigam, Venete T Social (1999) J Biotechnol Appl Biochem 29: 119-131.

35. Papone M, Talon R (1988) Factors affecting growth and lapse production by meat lacatobacilli strains and bronchotthrix thermosphacta. J appl bacterial 64(2): 107-115.

36. Priest FG (1977) Extracellular enzyme synthesis in the genus bacillus. Bacteriological reviews 41(3): 711-763.

37. Puvanakrishnan R, Dhar SC (1988) Enz Tech in beam house practice NICLAI publication, madras: 141

\section{ISSN: 2574-1241}

DOI: 10.26717/BJSTR.2018.10.001913

Leena Grace Beslin. Biomed J Sci \& Tech Res

This work is licensed under Creative

Commons Attribution 4.0 License

Submission Link: https://biomedres.us/submit-manuscript.php
38. Rao PV, Jayaraman k, Lakshman CM (1993) Production of lipase by canadida rugosa in solid state fermentation 1: determination of significant process. Variables proc Biochem 28(6): 385-289.

39. Rashind N, shimada Y, Ezaki S, Atomi H, lmanaka T (2001) Low temperature lipase from psychotropic pseudomonas sp Strain KB700A. Appl environ microbiol 67(9): 4064-4069.

40. Rathi P, Sazena RK, Gupta R (2001) A Novel alkaline lipase form burkholderia repacia for detergent formulation. process biochem 37 (2): 187-192.

41. Reetz MT, Jaegar KE (1999) Superior biocatalyst by directed evolution. Topics curr chem 200: 31-57.

42. Ruiz B, Farres A, Langely E, Masso F, Sanchez S (2001) Purification and characterization of an extracellular lipase from penicillium candidum. Lipids 36: 283-289.

43. Ruiz C, Falcocchio S, Pastor FI, Diaz P, Sasa L (2004) Activation and inhibition of candiala rugosa and bacillus related lipases by saturated fatty acids, evaluated by a new colorimetric micro assay 1672(3): 184191.

44. Saxena RK, Sheoran A, Giri B, Davidson S (2003) purification strategies for microbial lipases. J microbial methods 52(1): 1-18

45. Sharma R, Soni SK, Vohra RM, Jolly RS, Gupta LK (2002) production of extracellular alkaline lipase from bacillus sp. rsti and its application in ester hydrolysis. Ind microbiol 42: 49- 54.

46. Snellman EA, Colwell RR (2004) Acinetobacter lipases: molecules biology, biochemical properties and biotechnological potential. J ind microbial biotechnol 31(9): 391-400.

47. Snellman EA, Sullivan ER, Colwell RR (2002) purification and properties of the extracellular lipase, lip A, of Acinetobacter sp. RAG-1. Eur biochem 269(23): 5771-5779.

48. Sugai T, Katosh 0, Ohta, H (1995) In vitro 31: 11987-11998.

49. Sugihara A, Tani T, Tominaga Y (1991) purification and characterization of a novel thermostable lipase from bacillus sp 1-216. J biochem 109(2): 211-216.

50. Underkofler LA, RR Barton, SS Rennert (1957) Production of microbial enzymes and their application 9: 225-237.

51. Valsa AK, Achamma Thomas, Manoj Mathew, Mohan S, Manjula R (2003) Optimization of growth conditions for the production of extracellular lipase of vacillus my colds ind j microbiol 43: 67-69.

52. Vulfson E (1994) Industrial application of lipase in: lipase their structure, biochemistry and application. Wooley P, Peterson SB (Eds.) Cambridge university press, gb p: 277-288.

53. Wang Y, Srivastav KC, Shen GJ, Wang HY (1995) Thermostable alkaline lipase from a newly isolated thermophilic bacillus, strain A30-1 (ATCC 53841). j ferment bioeng 79(5): 433-438.

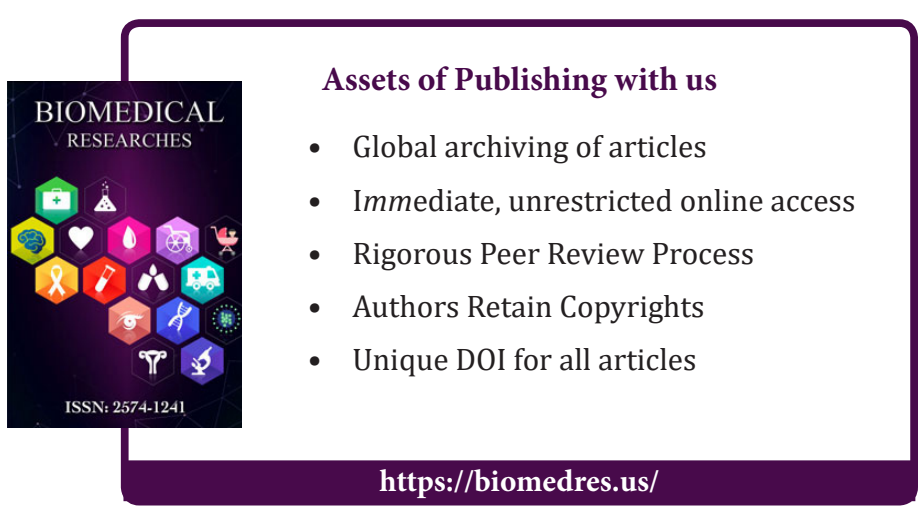

